\title{
The Regional Impact of 2008 Russia-Georgia War
}

Süleyman Erkan *

* Karadeniz Teknik Üniversitesi

E-mail: serkan@ktu.edu.tr

Copyright (C) 2015 Süleyman Erkan. This is an open access article distributed under the Eurasian Academy of Sciences License, which permits unrestricted use, distribution, and reproduction in any medium, provided the original work is properly cited.

\begin{abstract}
2008 Russia-Georgia war had a significant impact on not only fighting sides but also the countries in the region. Defeated Georgia lost the region of South Ossetia and Abkhazia and also faced with very serious economic and political problems. Altough Russia was the winner of the war, it also suffered a loss of international prestige and its relations with the West have become more problematic. While Turkey, whose relations with both sides have been in good condition, was undergoing economic losses, it was also in the centre of debates between the Western allies and Russia due to the Montreux Convention. Besides, Azerbaijan became irritated due to the Karabakh region and it was tough for Azerbaijan to establish balance betwwen Russia and the West on both oil and natural gas exports. The rapprochement between Turkey and Armenia may be considered as a reflection of this war.
\end{abstract}

Keywords: War, Russia, Georgia, Turkey, Azerbaijan

\section{Rusya-Gürcistan Savaşının Bölgesel Etkileri}

\section{ÖZET}

2008 Rusya-Gürcistan Savaşının gerek savaşan ülkeler, gerekse bölge ülkeleri üzerinde önemli etkileri oldu. Savaştan yenilgiyle çıkan Gürcistan, Güney Osetya ve Abhazya Bölgelerini tamamen kaybettiği gibi, çok önemli ekonomik ve politik sorunlarla karşı karşıya kaldı. Savaştan üstün bir askeri başarıyla çıkmasına rağmen, Rusya da uluslararası prestij kaybına uğradı ve Batı ile ilişkileri sorunlu hale geldi. Savaşan her iki ülke ile de iyi ilişkileri bulunan Türkiye bir yandan ekonomik kayıplara uğrarken diğer yandan Montrö Sözleşmesi nedeniyle Batılı Müttefikleriyle Rusya arasındaki tartışmaların muhatabı oldu. Bölge ülkelerinden Azerbaycan da hem Karabağ Sorunu nedeniyle tedirginlik yaşadı hem de petrol ve doğalgaz ihracatında Rusya ile Batı arasında denge kurmakta zorlandı. Türkiye ile Ermenistan arasında başlayan ilişkilerin normalleştirilmesi süreci de bu savaşın yansıması olarak görülebilir.

Anahtar Kelimeler: Savaş, Rusya, Gürcistan, Türkiye, Azerbaycan

\section{1-Giriş:}

1989’dan sonra, Sovyetler Birliği’nin dağılma sürecine girmesiyle birlikte, Kafkasya bölgesindeki etnik anlaşmazlıklar yeniden ortaya çıktı. Kuzey Kafkasya Bölgesindeki Çeçenistan ve İnguşedya benzeri etnik sorunlar Rusya Federasyonunun sınırları içerisinde ve doğrudan bu ülkenin bir sorunu olarak gelişmesine rağmen Güney Kafkasya Bölgesindeki 
sorunlar daha farklı olayların konusu olmuştur. Rusya kendi sınırları içerisindeki etnik temelli sorunlarda hiçbir şekilde ödün vermezken Azerbaycan ile Ermenistan arasındaki Karabağ Anlaşmazlığında tamamen çelişkili bir tutum izlemiştir. Gürcistan'ın Güney Osetya ve Abhazya bölgeleriyle yaşadığı anlaşmazlıklara ise doğrudan müdahale etmekte bir sakınca görmemiştir. Gürcistan'ın geçmişte Güney Osetya ve Abhazya sorunlarının yaratıcısı olarak Rusya'yı görmesi ve sorunları Rusya'ya rağmen çözme arzusu kendisini zorunlu olarak Batı'ya, NATO ve ABD'ne yaklaşmaya sevk etmiştir. Gürcistan'ın Orta Asya ve Hazar Bölgesindeki hidrokarbon kaynaklarının dünyaya ulaştırılması için elverişli bir güzergahta bulunması Batı'nın da bu ülkeyi önemsemesine neden olmuştur.

2003 Gül Devrimi'nden sonra Gürcistan ile Batı arasındaki yakınlığın artması Rusya'nın şiddetli tepkisiyle karşılaştı. Bir yıl sonra Ukrayna' da da benzer nitelikte Turuncu Devrim'in gerçekleşmesi Rusya'yı adeta bir kuşatılmışlık duygusuyla karşı karşıya bıraktı. Devrimden sonra iktidara gelen Sakaşvili'nin AB ve ABD ile çok yakın ilişkileri ve NATO'ya üyelik gayretleri Rusya'nın Gürcistan'ın ayrılıkçı bölgelerindeki bağımsızlık yanlısı hareketlere desteğini artırdı. Gerek Güney Osetya gerekse Abhazya 1991-1993 arasındaki çatışmalardan sonra fiilen Gürcistan'la bağlarını koparmışlardı. Sakaşvili'nin 2008 Ağustosunda, 2006 yılında bir referandumla bağımsızlığını ilan eden, Güney Osetya’ya askeri kuvvet göndermesi ile başlayan gerginlik Rusya ile Gürcistan arasında sadece beş gün sürecek bir savaşa yol açtı. Sakaşvili'nin Güney Osetya'ya askeri müdahalede bulunması da Rusya'nın Gürcistan'a çok büyük güçlerle karşılık vermesi de dünyada büyük bir şaşkınlığa neden oldu. Savaşın 2008 Pekin Olimpiyatları'nın açılış gününe rastlaması ise bu şaşkınlığı biraz daha artırmıştı. ( Donovan, 2009: 11 ) Dünyanın çok önemli bir finansal krizle karşı karşıya kaldığı bir anda bu savaşın ortaya çıkması bütün dünyada bir başka huzursuzluk kaynă̆ı idi.

Rusya-Gürcistan Savaşı Uluslararası toplumda olduğu gibi bölge ülkelerinde de büyük bir tedirginlik yarattı. Savaşta hiçbir varlık gösteremeyen ve Rusya'dan belki de umduğundan fazla karşılık bulan Gürcistan büyük problemlerle karşı karşıya kaldı. Askeri gücü önemli ölçüde zayıflarken ülkenin sivil tesisleri ve alt yapısı da büyük zarar gördü. Zaten var olan ekonomik sorunlar savaşın etkisiyle daha da derinleşti. Savaşa sebebiyet verdiği ve Batı'ya fazla güvenerek Rusya'nın tuzağına düştüğü gerekçesiyle Sakaşvili yönetimine karşı muhalefet artt1. ( Krastev, 2008: 08. 31 ) Savaştan sonra, küçük bir ülke olan Gürcistan'a karş1 orantısız bir müdahalede bulunduğu gerekçesiyle Rusya da uluslararası düzeyde önemli bir prestij kaybına uğradı. Savaştan Rusya ve Gürcistan'ın dışında kalan gerek bölge gerekse bölge dışı bir çok ülke de olumsuz yönde etkilendiler. Bunların başında Türkiye, Azerbaycan, Ermenistan, İran, Orta Asya Ülkeleri, Ukrayna, Doğu Avrupa Ülkeleri ve hatta Suriye, Çin, Tayvan ve Venezuella geliyordu. Bu ülkelerin bir kısmı doğrudan bir kısmı da dolaylı olarak savaşın etkisini hissettiler. ( Chicky, 2009: 4 ) Doğrudan etkilenen ülkeler arasında Savaşan ülkeler olan Gürcistan ve Rusya ile birlikte Türkiye, Azerbaycan ve Ermenistan ilk sırada yer aliyordu.

$\mathrm{Bu}$ çalışmada 2008 Rusya-Gürcistan Savaşının bu ülkelerdeki etkilerinin yan 1sıra Türkiye ve bölgenin diğer ülkelerindeki etkileri analiz edilecektir. 


\section{2-Savaşın Gürcistan Üzerindeki Etkileri}

Gürcistan'ın 2008 Savaşında Rusya karşısında hiçbir varlık gösteremeyerek birkaç gün içerisinde adeta teslim olması ülkede her alanda çok ağır birtakım yıkımlar meydana getirdi. $\mathrm{Bu}$ olumsuz gelişmelerin arasında askeri, ekonomik, politik ve psikolojik olanlar ilk sırada yer alıyordu. Gürcistan Rusya'ya oranla hem ekonomik hem de askeri bakımdan küçük ve zayıf bir ülkeydi. 1991'deki bağımsızlığının ilk gününden beri Güney Osetya ve Abhazya ile yaşamış olduğu etnik sorunlar adeta donmuştu. Kâğıt üzerinde kendisine bağlı bulunan bu bölgeler her geçen gün kendisinden biraz daha uzaklaşmakta ve adeta kopmaktaydı. Nitekim 2006 yılında Güney Osetya bağımsızlığını ilan etmişti. Rusya ise ayrılıkçı bölgelerdeki hareketleri destekliyordu. Sakaşvili 2004 seçimlerinde devlet başkanı olurken ayrılıkçı bölgelerde Gürcistan'ın yeniden kontrolü sağlayacağına söz vermiş ve ülkede nasyonalist duygular tavan yapmıştı. Bu duygularla 7 Ağustos 2008 gecesi Güney Osetya'ya asker sevk edince karşısında hiç ummadığı kadar Rusya'nın askeri gücünü buldu. Savaşın birkaç gün içerisinde kaybedilmesi Gürcistan'da büyük bir hayal kırıklığı ile birlikte aynı zamanda korku ve endişe yarattı. ( Chicky, 2009: 7 ) Korkuların başında Rusya'nın Güney Osetya'dan başka Gürcistan'ın tamamını işgal edeceği endişesi yer alıyordu. Çünkü Rusya kısa zamanda Güney Osetya bölgesi sınırlarını aşmış ve başta Gori olmak üzere Gürcistan topraklarına girmişti. Sakaşvili Yönetimi Batı'dan yardım için umutla beklerken Gürcistan halkında büyük bir karamsarlık hakimdi. ( Nichol, 2009: 1 ) Savaşın kaybedilmesinin yarattığı hayal kırıklı̆̆ işgal korkusuyla birleşerek kamuoyunda psikolojik bir travmaya dönüştü.

Savaş Gürcistan'ın Güney Osetya'yı yeniden kontrol etmeye çalışırken tamamen kaybetme tehlikesini de beraberinde getirdi. Bölgede daha önce yaşanan Gürcü-Oset çatışmaları zaten etnik nefret ve ayrılıklara sebep olmuştu. 2008 Ağustosunda Gürcistan'ın müdahalesiyle Güney Osetya'dan önce on binlerce Oset Halkı Kuzey Osetya'ya sığınırken, Rusya'nın müdahalesi ile de yine on binlerce Gürcü kökenli Gürcistan'a sığınmak zorunda kalmıştı. Gürcistan fiilen Güney Osetya topraklarını kaybetse bile hukuken kaybetmiş sayılmazdı. Ancak Oset Halkının Gürcistan'la bir arada yeniden yaşama arzularının tamamen sona erdiğine şüphe yoktur. En zor durumda da karşılıklı evlilik yapan aileler kalmıştı. ( Kırdar, 2008: 70 ) Savaştan sonra sivil halkın terk ettiği çatışma bölgelerinde yağma ve çapulculuk olayları artmış gerek Osetler'e gerekse Gürcülere ait yerleşim yerleri tamamen tahrip edilmişti. Güney Osetyalı sığınmacılar Gürcistan için çok önemli sosyal ve ekonomik problemler doğurdu. Evlerini terk eden ve yakınlarını kaybeden bir çok sığınmacı nedeniyle Gürcistan hükümeti çok zor durumda kaldı. ( Nichol: 11 ) Bir yandan savaşın kaybedilmesi diğer yandan sığınmacıların perişanlığı Gürcistan genelinde büyük bir karamsarlığa neden olmuştu. Savaş sonunda Gürcistan'ın Güney Osetya'dan sonra Abhazya ile de bağları fiilen sona ermişti. Çünkü Rusya savaşı Güney Osetya ile sınırlı tutmayarak Abhazya’ya da yaymıştı. Böylece, Gürcistan Güney Osetya'yı kontrol etmeye çalışırken bunu başaramadığı gibi Abhazya umutları da büyük ölçüde sona ermişti. 
Savaş Gürcistan ekonomisinin tamamen çökmesine neden oldu. Dünya Bankası ve diğer Uluslararası yardım ve finans kurumlarının hazırladıkları raporlara göre, savaşın Gürcistan'a maliyeti yaklaşık bir milyar dolar civarında idi. Savaştan sonraki ilk yıl için Gürcistan'ın acil olarak 394,5 milyon dolarlık yardıma ihtiyacı vardı. Ancak Gürcistan'ın ekonomik sorunlarını bütünüyle çözmesi için yaklaşık 4 milyar dolar gerekiyordu. ( Nichol: 12 ) Zaten ekonomik problemlere sahip olan Gürcistan savaştan sonra daha da büyük sorunlarla karşı karşıya kaldı. Kasaba ve köyler yanmış ve yıkılmış alt yapı tesisleri büyük ölçüde tahrip edilmişti. Yabancı yatırımlar tamamen sona ermiş, ithalat ihracatın dört katına çıkmıştı. Bu da Gürcistan parası Lari'nin büyük değer kaybetmesi anlamına geliyordu. ( Papava, 2009: 207-208 ) Özellikle savaşın son gününde Gürcistan Bankacılık sektörü çok büyük bir kriz riski ile karşı karşıya geldi. Rusya'nın ülkenin tamamını işgal edeceği korkusu ile vatandaşlar ve şirketler bankalardaki paralarını çekmeye başladılar. Bir gün içerisinde yaklaşık yarım milyarlık para bankalardan çekildi. Bir banka krizinden kaçınmak için Gürcistan Merkez Bankası Ticari Bankalara kredi güvencesi verdi ve faiz oranlarını bir hafta için \%12'den \%10'a indirdi. Böylece kötü-en kötü tercihi yapılmıştı. Aksi taktirde banka krizi genel bir ekonomik krize dönüşebilirdi. Buna rağmen bankalardan çekilen mevduatların Eylül 2008 sonunda ( savaştan 50 gün sonra ) sadece \%30’u geriye döndürülebildi. ( Papava: 2008 ) Ekonomik kriz toplumun bütün kesimleri üzerinde derin etkiler yarattı. Savaş sonrasında Gürcistan kamuoyu savaştaki ağır yenilgi, ayrılıkçı bölgelerin kaybı ve ağır ekonomik sorunları bir arada yaşamak zorunda kaldı. Bu olumsuzluklar tablosu kaçınılmaz olarak Sakaşvili yönetimine karşı muhalefeti harekete geçirdi.

Gürcistan-Rusya Savaşında, başlangıçta, muhalefet de dahil bütün siyasal gruplar Sakaşvili yönetiminin yanında yer aldılar. Bazı muhalefet grupları Sakaşvili'nin Güney Osetya'ya asker göndermesine sıcak bakmasalar da savaş başladıktan sonra sessiz kaldılar. Çünkü muhalefet liderleri “Vatan Haini " ve "Rusya Ajanı " damgası yemekten çekindikleri için Sakaşvili Hükümetine karşı bu anlama gelebilecek ifadeler kullanmaktan özellikle kaçındılar. Savaş sırasında yönetimi açıkça eleştirmek Rusya'nın ülkenin içişlerine karışmasına firsat verebilirdi. Hatta bütün muhalefet partileri önceliği Rusya'nın Gürcistan Topraklarından bir an önce çekilmesine vermişler, hükümetle hesaplaşmayı ise ikinci plâna bırakmışlardı. ( Mikhelidze, 2009: 3 ) 12 Ağustosta, savaşın ateşkesle sona ermesinin ardından, Sakaşvili yönetimine karşı muhalefet sessizliğini bozarak harekete geçti. Hükümet saldırıyı Rusya'nın başlattığını ve Gürcistan'ın da kendisini savunmak zorunda kaldığını ileri sürerken muhalefet ise Savaşın çıkmasından Sakaşvili yönetimini sorumlu tutmaya başladı. Muhalefetteki partilerden Cumhuriyetçi Parti Başkanı Ivlian Khaindrava basına verdiği bir mülakatta savaşı Sakaşvili'nin başlattığını açıkça belirtti. Diğer muhalefet liderleri de savaşın Sakaşvili'nin tarafından başlatıldığı ancak Rusya'nın tuzağına düşüldüğü konusunda görüş birliği içerisinde idiler. ( Kımıtaka, 2009: 234 )

Eylül 2008'de, muhalefet partileri savaşın çıkarılmasının soruşturulması yönünde parlamentoda bir araştırma önergesi verdiler. Önergede açıkça ABD’nin uyarmasına rağmen neden Rusya'nın tuzağına düşüldügüünün araştırılması isteniyordu. Cumhuriyetçi Parti Lideri Khaindrava, Eski Moskova Büyükelçisi Erosi Kitsmarishvili ve Eski Parlamento Başkanı Nuno Burjanadze başta olmak üzere bütün ileri gelenlerde, muhalefet ve kamuoyunda böyle 
bir psikoloji hakimdi. Muhalefet Sakaşvili'nin hatasından çıkan savaşla ülkenin bir kaosa sürüklendiğini ve Güney Osetya ile Abhazya'nın tekrar kazanılması için savaşsız politikalar izlenmesi gerektiğini savunmaya başladı. Hatta bazı önde gelen muhalefet partileri anayasada değişiklik yapılmasını ve Başkanlık Sistemi yerine Parlementer Cumhuriyete geçilmesini istediler. ( Kımıtaka: 240 ) Ekim ayından itibaren muhalefet cephesinde Sakaşvili'ye yönelik eleştirilerin dozu daha da artmaya başladı. Nuno Burjanadze tarafından Birleşik Gürcistan Demokratik Hareketi adıyla yeni bir muhalefet partisi kuruldu. Eski Başbakanlardan Zurab Noghaideli de 2008 sonlarında yeni bir parti kuracağını açıkladı ve diğer muhalefet partileri olan Yeni Să̆ Parti ve Cumhuriyetçi Parti ile ittifak yapacağını söyledi. Gürcistan'ın eski Birleşmiş Milletler Büyükelçisi Irakli Alasania'nın da katıldığı muhalefet ittifakı Sakaşvili'yi istifaya çağırarak erken parlamento ve başkanlık seçimleri istediler. ( Nichol: 12 ) Sakaşvili yönetimine yönelik muhalefetin başlattığı kampanyalara halk da geniş şekilde destek verdi. Tifliste 2009 Mart ayından itibaren sivil toplum kuruluşları ve halkın katılımıyla hemen her gün Sakaşvili yönetimi aleyhinde gösteriler yapıldı. Ancak bu gösterilerde herhangi bir taşkınlık yaşanmamış ve rock konserleri ve diğer sanatsal etkinlikler protesto aracı olarak kullanılmıştı. ( Kımıtaka: 234 )

Savaştan sonra Gürcistan dış politikasında da uluslararası destek arayışları hızlandı. Gürcistan yönetimi Bağımsız Devletler Topluluğundan çekilirken Rusya'ya karşı BM, AB, NATO ve ABD’nin desteğini sağlamaya çalıştı. ( Alexandrova-Arbatova; 2009: 292 ) Ancak savaştan önce Gürcistan'ın NATO ve AB üyeliğine sempati ile yaklaşan bu kuruluşlar savaştan sonra Rusya'nın askeri müdahalesini kınamalarına rağmen üyelik konusunu riskli bulmaya başladılar. Gürcistan politik çevrelerinde de Batı'nın kendilerine umulan desteği vermediğine dair yaygın bir algı oluştu. Hükümet ve daha çok muhalefet çevrelerinde oluşan bu alg1 Rusya ile savaşın bir yanılgı olduğu görüşünü kuvvetlendirdi. Bununla birlikte savaşın durdurulmasında Batı'nın ve özellikle AB'nin oynadığı rol de dikkatlerden kaçmadı. Rusya ile Güney Osetya ve Abhazya Sorunları nedeniyle ilişkilerin düzelme olasılığı bulunmadığına göre, Gürcistan'ın ekonomik sorunlarını aşabilmesinin yolu yine Batı ile yakınlaşmaktan geçiyordu. Savaştan sonra Rusya'nın iktidardan düşmesini beklediği Sakaşvili'nin koltuğunu 2012 seçimlerine kadar koruyabilmesi büyük ölçüde Batı'nın Gürcistan'a verdiği destek sayesinde olmuştu.

\section{3-Savaştan Sonra Rusya}

Rusya'nın Güney-Osetya ile Gürcistan arasındaki çatışmaya müdahale etmesi Gürcistan'1 cezalandırmak olduğu kadar Gürcistan üzerinden Batı Ülkelerine verilmiş bir mesajdı. Savaştan sonra Rusya Devlet Başkanı Medvedev'in Washington Post ve BBC'ye vermiş olduğu röportaj da bu açık şekilde belirtilmişti. Medvedev Rusya'nın güvenliği ile ilgili eski Sovyet sahalarındaki gelişmelere seyirci kalmayacaklarını ve müdahalenin en doğal hakları olduğunu belirtmişti. Rusya Devlet Başkanı'nın bu açıklamaları, bazı siyasal yorumcular tarafından, 1968'deki Sovyetlerin Çekoslavakya'yı işgalindeki “ Brejnev Doktrini “ ne benzetilerek “ Medvedev Doktrini “ olarak adlandırıldı. ( Sushko, 2008: 3 ) 
Rusya bu savaşla açıkça Batı ile Rusya'nın çıkarları için çatışmadan kaçınmayacağını gösterdi. Savaş nedeniyle Avrupa Konvansiyonel Kuvvetler Anlaşmasını askıya aldığını açıklaması bunun en belirgin göstergesiydi. ( Chicky: 14 ) Savaştan sonra da Rusya Bağımsız Devletler Topluluğu'nun 2008'deki Bişkek Zirvesi'nde topluluğun barışı koruma misyonunun resmen sona erdiğini açıkladı ve Gürcistan'ın üyeliğinin askıya alındığını belirtti. ( Mikhelidze: 6 )

Savaşın bölgenin güvenlik dinamiklerinde Rusya lehine önemli getirileri oldu. Rusya'nın bağımsızlıklarını ilân eden Güney Osetya ile Abhazya'yı savaştan iki hafta sonra, 26 Ağustosta, tanıması kendisine sınırlarında yeni güvenlikli alanları kazandırdı. Çünkü Rusya ayrılıkçı bölgelerin bağımsızlıklarını tanımakla kalmamış her ikisinde de elçilik açacağını açıklamıştı. Nitekim Rusya 17 Eylül 2008'de hem Güney Osetya hem de Abhazya ile Dostluk ve İşbirliği anlaşmaları imzaladı. ( New York Times, 2008: 08, 27-Nichol: 13 ) Böylece Gürcistan'ın NATO üyeliği gerçekleşse bile Güney Osetya ile Abhazya NATO ile Rusya arasında tampon bölgeler oluşturacaktı. Moskova tarafından bölgedeki bu iki yeni ünitenin tanınması kendisine bu yönde büyük avantajlar sağladı. Rusya'nın bölgedeki fiili varlığı daha da arttı. Tiflis ile Viladi Kafkas arasındaki ana bağlantı olan Roki Geçidi Rusya'nın kontrolü altına girdi. Aynı zamanda Güney Kafkasya’yı Kuzeyden ayıran dağlar zinciri ile Karadeniz'in Doğu sahillerindeki 200 km. lik bir koridor Rusya'nın Güney Kafkasya/Trans Kafkasya sınırlarında bütünüyle güçlenmesine sebep oldu. Özellikle BaküTiflis-Supsa koridoru Rusya'nın askeri kontrol zincirine dahil oldu. ( Foucher/Giuliani, 2008: 3 ) Güney Kafkasya'daki transit enerji boru hatları Rusya'nın tehdidi altına girdiğinden Batı ile yeni bir soğuk savaşın eşiğine gelindi. Rusya'nın savaştan sonra geri adım atmaması ve Gürcistan'la birlikte Güney Kafkasya ülkeleri üzerinde tehdit oluşturması nedeniyle ABD Polonya ile 14 Ağustos 2008'de bu ülkeye nükleer füzeler yerleştirilmesi konusunda bir anlaşmaya vardı. ( Chossudovsky/Global Research, 2008: 08.22 ) Ancak ne ABD’nin bu adımı ne de NATO'nun 19 Ağustostaki Brüksel Toplantısında almış olduğu kararlar Rusya tarafından dikkate alınmadı. Artık Rusya Güney Kafkasya bölgesinde çok önemli stratejik avantajlar kazandı. ( Karabayram, 2011: 27 ) Rusya'nın bu yeni kazanımlarından Gürcistan dışındaki diğer bölge ülkelerinin de memnun kalmadıkları bir sır değildi.

2008 Savaşı, Rusya'da Putin'in ne kadar vazgeçilmez bir siyasi aktör olduğunu da kanıtlamıştır. Putin, İzlemek için gittiği Beijing Olimpiyatlarının açılış töreninden erken dönerek derhal savaş bölgesine, Viladikafkas'a, gitti. Savaştan sonra Rusya kamuoyunun gözünde zafer kazanmış bir kahraman olarak yer edindi. Zafer siyasi geleceğini daha da garanti altına almasına yardım etti. Savaştan önce Rusya kamuoyunda eleştirilen Putin'in otoriterliği artık eskisi kadar konuşulmaz oldu. Ancak Rusya’nın savaşta ve savaş sonrasında bölgede elde ettiği fiili kazanımlar dış politikada aynı başarıyı getirmedi. Rusya kendisi tarafından tanınmış olan Güney Osetya ve Abhazya'nın bağımsızlıklarının diğer devletlerce de benimseneceği umuyordu. Bu gerçekleşirse Rusya Batı'dan Kosova'nın rövanşını almış olacaktı. Ancak buna Venezuella ve Bolivya'daki marjinal rejimlerden başka destek veren hiçbir ülke olmadı. Özellikle Bağımsız Devletler Topluluğu'nun bile Rusya'yı desteklememesi Rusya'nın hem dünyadaki prestiji açısından yıkıcı oldu hem de bir yalnızlığa sürüklendi. Eski Sovyet Cumhuriyetleri dahi Rusya'ya dönmeye yanaşmadılar ve ayrılıkçı 
bölgeleri tanımadılar. Bişkek Zirvesi'nde Kazakistan'ın, savaşı sona erdiren Altı Maddelik Anlaşma'ya tarafların uymasını istemesi ( Mikhelidze: 8 ) aslında Rusya'ya daha fazla ileri gitme uyarısıyd.

Rusya tanıma konusunda gerekli dış desteği bulamadığı gibi NATO-Rusya Konseyi de askıya alındı. Rusya'nın G-8 Üyeliğinden çıkarılacağı söylendi ve nitekim G-8 Ülkeleri savaştan sonraki ilk toplantısını Rusya olmadan yaptı. Rusya'nın Dünya Ticaret Örgütü'ne üyeliği de engellenmeye çalışıldı. ( Milliyet, 2008: 08, 22 ) Bu Rusya'yı pes etmeye değil fakat biraz daha temkinli hareket etmeye yöneltti. Nitekim Eylül Ayı başlarında Avrupa Birliği adına hareket eden Sarkozy’nin aracılığı ile yeni bir anlaşmayı imzalamayı ve savaş zamanında bölgeye gönderdiği askerleri geri çekmeyi kabul etti. Bağımsızlığını ilân eden Güney Osetya Yönetiminin bölgenin Rusya ile birleşeceği yönündeki açıklamasını da benimsemedi ve Güney Osetya'nın bağımsız kalacağını açıkladı. Rusya'nın bu tavrı Abhazya'yı da etkiledi. Abhazya Lideri Sergei Bagapsh bağımsız olarak kalacaklarını fakat Rusya ile güçlü ilişkiler kuracaklarını açıkladı. ( Nichol: 13 )Soruna bütünüyle çözüm bulunması amacıyla Ekim 2008'de Cenova Konferansı düzenlenmesi kararlaştırılmıştı. Rusya bu konferansa elinde bölgede elde ettiği önemli kazanımlarla katıldı. Ancak Konferanstan bu güne kadar sorunun tüm taraflarının kabul edecekleri bir uzlaşma çıkmış değil. Sorunun çözümsüzlüğünden uzun vadede Rusya'nın kazançlı çıktığına şüphe yok. Hatta günümüzde Ukrayna'da yaşanan olayların Rusya'nın 2008 Savaşında Kafkasya'da elde ettiği kazanımların devamı olduğunu söylemek de abartı sayılmaz.

\section{4-Savaş ve Türkiye}

Rusya-Gürcistan Savaşında, savaşan ülkeler dışında, bölgede en çok etkilenen ülkelerin başında belki de Türkiye gelmektedir. Türkiye'nin savaşın tarafları olan hem Gürcistan hem de Rusya ile yakın ilişkileri vardı. Hatta anlaşmazlık bölgeleri olan Güney Osetya ve Abhazya ile de tarihi bağlara sahipti. Bununla birlikte savaş nedeniyle Türkiye'nin karşılaştı̆ğ zorluk sadece dost olduğu iki ülkenin çatışmasıyla da sınırlı değildi. Böyle olsaydı Türkiye'nin savaş karşısında tarafsız bir politika izlemesi daha kolay olabilirdi. Ancak, Türkiye'nin üyesi olduğu NATO, tam üyelik müzakereleri yürüttügü Avrupa Birliği ve müttefiklik düzeyinde ilişkilere sahip olduğu Amerika Birleşik Devletleri'nin Gürcistan'1 desteklemeleri Türkiye'nin tarafsızlık politikasını zorlaştırmıştır. Türkiye açısından bir diğer zorluk da süreçte Montrö Boğazlar sözleşmesinin ihlâl edilip edilmediği tartışmasıydı.

Türkiye ile Gürcistan arasındaki ilişkiler Gürcistan'ın Sovyetlerden bağımsızlığını elde ettiği 1991'den itibaren oldukça iyi idi. Bağımsızlıkla birlikte Güney Osetya ve Abhazya Özerk Bölgeleriyle yaşadığı çatışmaları Türkiye sınırında bulunan Acaristan Özerk Bölgesi ile yaşamaması biraz da Türkiye'nin bu ülkenin toprak bütünlüğüne duyduğu saygının sonucuydu. Buna karşılık Gürcistan da Kafkasya Bölgesindeki etnik ve politik çatışmalar karşısında Azerbaycan'la birlikte Türkiye'nin en önemli partnerlerinden biriydi. Bakü-TiflisCeyhan ( BTC ) Petrol Boru Hattı, Bakü-Tiflis-Erzurum ( BTE ) Doğalgaz Boru Hattı ve Bakü-Tiflis-Kars ( BTK ) Demiryolu iki ülkenin partnerliğindeki en güçlü bağları 
oluşturmaktaydı. Ayrıca Türkiye Gürcistan'a silah satışı yapıyor cephane veriyor ve ordusunu eğitiyordu. Savaştan önce, özellikle 2003 Gül Devrimi'nden itibaren, Türkiye ile Gürcistan arasındaki ekonomik ilişkiler de önemli bir büyüme meydana gelmişti. İnşaat sektörü öncelikli olmak üzere yaklaşık 100 Türk Şirketi'nin Gürcistan'daki yatırımları 600 milyon doları buluyordu. İki ülkenin ortak yatırımları bulunduğu gibi savaş öncesindeki ticaret hacmi de 1 milyar dolar civarında idi. ( Kırdar: 64 ) Gürcistan Türkiye'nin sınır komşusu olan ülkeler arasında belki de sorunsuz olduğu tek ülkeydi.

Türkiye'nin Gürcistan'la olduğu gibi Rusya ile de çok önemli ilişkileri vardı. Bunların başında ekonomik ilişkiler ilk sırada geliyordu. Türkiye BTC ve BTE projelerinde yer almasına rağmen tükettiği doğalgazın \%64'ünü ve petrolün de \% 40'ını Rusya'dan alıyordu. Türkiye ile Rusya arasındaki ticaret hacmi savaş öncesinde 27 milyar dolardı ve bir yıl sonra bunun 38 milyar dolar olacağı hesaplanıyordu. Rusya da Türkiye'nin en güçlü ticari partneri olmasını ve Almanya'nın yerini almasını umuyordu. Türk inşaat sektörüne bağlı şirketlerin Rusya'da dev yatırımları bulunduğu gibi bir çok süper market zincirinin şubeleri de faaliyet gösteriyordu. Türkiye'nin sebze ve meyve ihracatında Rusya ilk sirada geliyordu. Ayrica Türkiye'ye en çok turist de Rusya'dan gelmekteydi. Bundan başka Türkiye Rusya'nın NATO ile ortaklık ilişkilerini memnunlukla karşılıyor ve Dünya Ticaret Örgütü ( DTÖ )'ne üyeliğini destekliyordu. ( Mikhelidze: 11, Kırdar: 64 )

2008 Rusya-Gürcistan Savaşının çıkması Türkiye için son derece can sıkıcı bir gelişmeydi. Türk Dış Politikası bir yandan Rusya ile ilişkileri bozmadan komşusu Gürcistan’a yardım yapmak, diğer yandan da başta NATO olmak üzere mensubu olduğu Batı kuruluşlarının alacağı kararlara katılmak gibi son derece zor bir durumla karşı karşıya kaldı. Bütün ilgili taraflarla ilişkileri bozmamak için bir hokkabaz kıvraklığı ile hareket etmek gerekiyordu. Savaşın çıtı̆̆ı 7 Ağustos günü Başbakan Recep Tayyip Erdoğan Bodrum'da ailesiyle birlikte tatilini geçiriyordu. Dışişleri Bakanı Ali Babacan sırasıyla Rusya, Gürcistan ve ABD Dışişleri Bakanlarıyla görüşerek çatışmaların durması için girişimlerde bulundu. TBMM Başkanı Köksal Toptan da çatışan taraflara itidal çağrısında bulundu. Basında Başbakan Erdoğan'ın Rusya Başbakanı Putin'le bir telefon görüşmesi yapmak istediği fakat Putin'in telefonuna çıkmadığı yönündeki haberler 12 Ağustosta bizzat Erdoğan tarafından yalanlanmıştı. Bununla birlikte Rusya basınında Türkiye'nin Gürcistan'a silah sattığ haberleri can sıkıntısına sebep oldu. Erdoğan bu konuyla ilgili olarak, " Bütün ülkeler ürettiklerini bir başka ülkeye satarlar. Bizim de değişik ülkelere satışlarımız vardır. Biz de silâhlarımızı nerelerden temin ediyoruz? Rusya'dan temin ediyoruz. Yaptığımızın suç olduğu düşünülüyorsa, farklı bir yanlıştır” demişti. ( Milliyet, 2008: 08.12 ) Başta ABD olmak üzere Batılı ülke ve kuruluşların Rusya'ya karşı sert açıklamaları art arda gelmeye başlayınca Türkiye savaş karşısında daha somut bir adım atmaya karar verdi ve Başbakan Erdoğan tatilini yarıda keserek hem Moskova'yı hem de Tiflis'i ziyaret etmeye karar verdi.

Erdoğan 13 Ağustosta Moskova'ya gitti ve bu uluslararası çevrelerce yıldırım ziyaret olarak adlandırıldı. Rusya yönetimi Erdoğan'ı en üst düzeyde ağırladı. Önce Rusya Devlet Başkanı Medvedev'le görüşen Erdoğan ardından Başbakan Putin'in de yer aldığı bir çalışma yemeğine katıldı. Görüşmelerde Türkiye'nin savaşın ikinci gününde ortaya attığı “ Kafkasya İstikrar Paktı “ kurulması önerisine Rusya'dan destek geldi. Bunun hedefi Kafkasya Sorunlarının bölgesel işbirliği ile çözülmesiydi. İttifakta Türkiye ile birlikte Rusya, Gürcistan, Azerbaycan ve Ermenistan da yer alacaklardı. Böyle bir girişim Türkiye tarafından 1990'ların başında yine gündeme getirilmiş fakat Azerbaycan ve Ermenistan arasında yaşanan sorunlar nedeniyle gerçekleşememişti. Görüşmelerde Erdoğan ayrıca Karadeniz Ekonomik 
İşbirliği'nin de soruna müdahil olmasını istemişti. ( Milliyet, 2008: 08.14 ) Başbakan Erdoğan Moskova ziyaretinin ertesi günü Tiflis'e giderek Devlet Başkanı Sakaşvili ile buluştu ve İstikrar Paktı Planını onunla da görüştü. Bu plan 20 Ağustosta Erdoğan tarafından Bakü'de Devlet Başkanı Aliyev'e ve Eylülde de Erivan'da Cumhurbaşkanı Abdullah Gül tarafindan Cumhurbaşkanı Sarkisyan'a da sunuldu. ( Alirıza, 2008: 1 ) Ancak Türkiye'nin Kafkasya ülkeleriyle başlattığı bu İstikrar Paktı Planının ABD tarafından pek hoş karşılanmadığı görüldü. ABD'nin Dışişleri Bakanlığı'nın Avrupa ve Asya İşlerinden Sorumlu Müsteşar Yardımcısı Matt Bryza, Erdoğan'ın ani Moskova ziyareti ve ortaya attığı projenin kendilerini şaşırttığını söyledi. ( Milliyet, 2008: 08.20 ) Ancak bu işbirliği hiçbir zaman gerçekleşmedi.

Savaş sırasında ve sonrasında Türkiye, boğazlar ve Montro nedeniyle, hem Rusya ile hem de Batılı ülkelerle sorunlar yaşadı. Türkiye Gürcistan'a insani yardım ulaştırılmasına yardımcı olmaya çalışırken diğer taraftan da Montro sözleşmesinin ihlâl edilmemesi için çok dikkatli davranmaya çalıştı. Bununla birlikte Rusya tarafından defalarca Montro'nün ihlâl edildiğine yönelik suçlamalar eksik olmadı. Savaştan önce Romanya'nın Köstence Limanı'nda NATO'nun çoğu Almanya Donanmasına ait savaş gemilerinin bulunması Karadeniz'de bir gerginliğe neden olurken Rusya bir provokasyonla karşı karşıya olduklarını ileri sürmüş ve Türkiye'ye rahatsızlığını bildirmişti. NATO'dan, gemilerin planlı tatbikat için savaştan çok önce Türkiye'ye yapılan bildirimle Karadenizde bulundukları ve Montro'nün ihlal edilmediği açıklaması gelmesine rağmen Rusya ikna olmamıştı. ( New York Times, 2008: 08.28 )) Türkiye gerginliğin faturasının kendisine kesileceğinden endişe duyarak Rusya'ya güven vermek ve onu ikna etme çabalarına girişti. Türk Deniz Kuvvetlerine bağlı Donanma Komutanı ile Rus mevkidaşı Karadeniz'de bir firkateynde bir araya gelerek konuyu yüz yüze görüştüler. Gerek bu ikili görüşme gerekse Türkiye'nin ABD'ne ait 140.000 tonaj büyüklüğünde iki yardım gemisinin Karadeniz'e geçişine izin vermeyişi Rusya'yı biraz da olsa rahatlatmıştı. ( Alirıza: 2 )

Türkiye, bütün bu zorlukları göz önünde bulundurarak, savaş karşısında resmi bir pozisyon almamaya bilhassa özen gösterdi. Bölgesel partneri Gürcistan'ı açıktan savunmadığ gibi Rusya karşısında da ilişkilere zarar verecek davranışlardan uzak durmaya çalıştı. Başbakan Erdoğan'ın, “ Biz bir taraftan ABD’nin en yakın müttefikiyiz, diğer taraftan Rusya ile çok önemli ticari ilişkilerimiz var. Biz Türkiye'nin çıkarları neyi gerektiriyorsa onda kararlıyız “ söylemi Türkiye'nin çok yönlü tarafsızlığının bir göstergesiydi. ( Mikhelidze: 11 ) Bununla birlikte Türkiye'nin tarafsızlık politikası bütün ilgili taraflarla siyasi ilişkilerine zarar vermese de ekonomik ve ticari ilişkilerinde kayıplara yol açmıştır. Türkiye'nin Gürcistan'daki yatırımları bu ülkenin savaş yüzünden düştüğü finansal kriz yüzünden büyük ölçüde askıya alındığı gibi, Rusya ile ticaretinde de önemli daralma meydana gelmiştir. Ekonomiden sorumlu Devlet Başkanı Kürşat Tüzmen'e göre, savaş nedeniyle Rusya ile ticarette yaşanan kayıp 3 milyar dolardı. ( Kırdar: 66 ) Diğer taraftan savaşın Dünya'da meydana gelen finansal kriz dönemine rastlaması göz önüne alındığında uğranılan zararların ekonomiye yansımasının daha da yüksek olduğu ortadadır. Bu nedenle Türkiye Kafkasya'daki iki komşusu arasındaki ilişkilerin bir an önce normalleşmesine büyük önem vermiş ve bunun için çaba harcamıştır. Eğer Türkiye'nin Kafkasya İstikrar Paktı önerisi hayata geçirilebilseydi hem bu ekonomik kayıpları bir daha yaşamaz hem de bölgede barışa öncülük yapabilirdi. ( Antonenko, 2009: 266 ) Bununla birlikte, Türkiye'nin savaștan sonra gerek Rusya ile gerekse Gürcistan'la ilişkilerinin olumlu yönde gelişmesi büyük ölçüde izlemeye çalıştığı tarafsız dış politikanın sonucunda gerçekleşmiştir. 


\section{5-Savaşın Azerbaycan ve Ermenistan'a Etkileri}

2008 Savaşından Güney Kafkasya'nın diğer ülkeleri olan Azerbaycan ve Ermenistan'ın ülke politikaları da da etkilenmiştir. Azerbaycan 1996'da kurulan ve etnik ayrılık sorunları bulunan ülkeler ittifakı anlamına gelen GUAM ( Gürcistan-Ukrayna-Azerbaycan-Moldova İttifak1 ) nın bir üyesiydi. Ancak Güney Osetya yüzünden çıkan savaş sırasında bu ittifaka rağmen Rusya'dan çekindiğinden sessiz kalmayı tercih etti. İttifak üyelerinden sadece Ukrayna Rusya'yı açıktan kınayabilmişti. ( Mikhelidze: 8 ) Rusya-Gürcistan savaşı karşısında Azerbaycan dış politikası çok kritik bir aşamadan geçti. Azerbaycan'ın karşı karşıya kaldığı pozisyon Türkiye'ninkine çok benziyordu. Bu süreçte Bakü Rusya'ya karşı düşmanca bir tutum takınmaktan özenle kaçındığı gibi $\mathrm{AB}$ ve NATO ile de ilişkilere dikkat etmeye çalıştı. Diğer yandan Gürcistan ile de komşuluk ilişkilerini sürdürmeye gayret etti. Azerbaycan'ın kriz sürecinde izlediği politika İkinci Dünya Savaşından sonra Finlandiya'nın Sovyetlerle Batılı Ülkeler arasında izlediği politikaya benzetilerek “ Finlandization “ olarak tanımlanmıştır. ( Valiyev, 2010: 1 ) Azerbaycan'1 böyle bir politika izlemeye zorlayan nedenlerin başında şüphesiz ki Ermenistan'la yaşamakta olduğu Karabağ Sorunu ve Güney Kafkasya üzerinden dünyaya ulaşan petrol ve doğalgaz kaynaklarıydı. Azeri doğal kaynaklarının Güney Kafkasya'dan geçen üç güzergahı bulunuyordu. Bunlardan ilki 1998'de faaliyete geçen ve Azerbaycan petrolünü ilk kez ülke dışına nakleden Bakü-Supsa petrol boru hattıyd. Ayrıca yukarıda belirtilen BTC ve BTE enerji hatlarının birinci partneri de Azerbaycan'dı. ( Foucher/Giuliani: 3 ) Azerbaycan'ın çıkarları bütün taraflarla iyi geçinmeyi gerektiriyordu.

Savaştan Azerbaycan'ın Gürcistan'la ekonomik ve ticari ilişkileri de olumsuz yönde etkilendi. Savaş sırasında Azerbaycan Gürcistan'ın Karadeniz kıyısındaki limanları Rusya'nın işgali altına girince bu limanlar üzerinden ihraç ettiği petrol ve petrol ürünlerinin sevkiyatını durdurmak zorunda kaldı. ( Milliyet, 2008: 08.17 ) Savaşta BTC ve BTE' ye bir saldırı olmamasına rağmen Azerbaycan bu hatlardaki petrol ve doğal gaz akışını da güvenlik riski nedeniyle askıya aldı. Bu kaynakların ihraç edilememesi ülke ekonomisini zor durumda bırakacağından Bakü Yönetimi alternatif rotalar kullanmak zorunda kaldı. Novorosyk yoluyla Rusya'ya ve Neko Port ile de İran'a yöneldi. Rusya Azerbaycan'ın petrol ürünlerini ihraç edemeyişinin ülkeyi zor durumda bıraktığının farkında idi. Bu nedenle Azerbaycan'a ihraç edebileceği bütün doğalgazı satın alma önerisinde bulundu. Ancak Bakü Yönetimi ABDRusya rekabetinde taraf tutma durumuna düşmemek için yine de dengeli bir politika izledi ve tüm doğalgazı Rusya'ya satmaya yanaşmadı. ( Mikhelidze: 9 ) Diğer taraftan Azerbaycan'ın Gürcistan'la da ekonomik ve politik yakınlığı vardı. Savaş öncesinde Azerbaycan iş adamlarının Gürcistan'daki ekonomik yatırımlarında büyük artış olmuştu. Azerbaycan Devlet Başkanı İlham Aliyev'in 2008 Davos Ekonomik Forumu'nda belirttiğine göre, Azerbaycan şirketlerinin Gürcistan'daki yatırımları 3 milyar dolardı ve bunların her iki ülke ekonomisine büyük katkıları vardı. Gürcistan petrol piyasasında Azerbaycan Devlet Şirketi olan SOCAR adeta bir monopoldü. ( Valiyev: 4 ) Savaşın Gürcistan'da yarattığı ekonomik çöküş Türkiye gibi Azerbaycan şirketlerinin faaliyetlerinin de büyük ölçüde askıya alınmasına neden olmuştu.

Rusya-Gürcistan savaşının Azerbaycan üzerinde yarattığı etkilerden biri de Karabağ Sorunu konusunda yaşanan hareketlilik olmuştur. Aslında bu hareketlilik Azerbaycan kadar sorunun diğer tarafı olan Ermenistan ve soruna her zaman duyarlı olan Türkiye'yi de devreye sokmuştur. Savaştan sonra Rusya Devlet Başkanı Medvedev " Donmuş Sorunlar " a çare arayacaklarını söylemişti. ( Arbatova-Alexandrova: 293 ) Bu açıklama gerek Azerbaycan 
gerekse Ermenistan cephesinde heyecan yarattı. Açıklamadan kısa bir süre sonra da Azerbaycan Lideri Aliyev ile Ermenistan Devlet Başkanı Sarkisyan Moskova'da Medvedev'le bir araya gelerek Karabağ Sorununu müzakere ettiler ve bir deklerasyon imzaladılar. Deklerasyon, Karabağ Sorununa " Madrid Prensipleri " çerçevesinde, Avrupa Güvenlik ve İşbirliği Teşkilâtı Minsk Grubu'nun çabaları ile çözüm bulunmasını öngörmekteydi. Buna göre, Ermenistan Azerbaycan topraklarını tahliye edecek ve Karabağ Sorunu referandum yoluyla çözülecekti. Toplantı sonrasındaki açıklamalarında, Gerek Aliyev gerekse Sarkisyan sorunun çözümü için çabalarını yoğunlaştıracaklarına dair açıklamalar yaptılar. ( Arbatova-Alexandrova: 293 ) Rusya, 2008 Savaşından hemen sonra, böyle bir toplantı düzenlemekle bir yandan aslında Kafkasya Bölgesinde savaşı isteyen tarafın kendisi olmadığını göstermek, diğer taraftan da Güney Kafkasya'nın diğer iki ülkesinin Gürcistan'ın ve Batı'nın yanında yer alma olasılığını ortadan kaldırmak istedi. Azerbaycan cephesinde ise Savaştan sonra Rusya'nın Güney Osetya ve Abhazya'nın bağımsızlıklarını tanımış olması Karabă için de bir korku yaratmıştı. Eğer Azerbaycan açıktan Rusya karşıtı cephede yer alırsa Rusya Karabağı da tanıyabilirdi.

Savaşta Ermenistan da tarafsızlığını korudu. Ancak savaş nedeniyle 670 milyon dolarlık bir zarara uğradı. Çünkü Ermenistan dış ticaretinin \%70'ini Gürcistan limanları üzerinden gerçekleştiriyordu. Ermenistan yöneticilerine göre eğer savaşta taraf tutulmuş olunsaydı bu miktar daha fazla olabilirdi. ( Mikhelidze: 10 ) Gürcistan üzerinden ticaretin zora girmesi Ermenistan'ı İran'a daha fazla yöneltti. Ancak Batı'nın İran'la ilişkilerinin iyi olmaması hem de bu ülke üzerinden ticaretin masraflı olması Ermenistan'1 zor durumda biraktı. Bir yandan Rusya'nın başlattı̆ğ Karabağ Sorununa çözüm arama girişimi diğer taraftan Batı'nın Ermenistan'1 boğulmaktan kurtarma gayretleri Türkiye ile Ermenistan arasındaki ilişkilerin normalleştirilmesi sürecinin hazırlayıcısı oldu. Türkiye Cumhurbaşkanı Abdullah Gülün Erivan'daki, Ermenistan Cumhurbaşkanı Serj Sarkisyan'ın da Bursa'daki milli futbol karşılaşmalarını izlemeleri ve iki ülke arasında imzalanan protokoller çok önemli bir gündem oluşturmuştu. Futbol Diplomasisi adı verilen bu süreç Azerbaycan'da rahatsızlık yaratmış ve Bakü'de Türkiye'ye verilen doğalgazın kesilmesi veya fiyatının artırılması kararlaştırılmıştı. İki ülke arasındaki ilişkiler ancak Cumhurbaşkanı Abdullah Gül'ün Bakü'yü ziyareti ve Azerbaycan'ın endişelerini gidermesiyle normalleştirilebilmişti. ( Mikhelidze: 11 ) Bununla birlikte, Rusya-Gürcistan Savaşının etkisiyle Güney Kafkasya ülkeleri arasındaki ilişkilerde başlayan haraketlilik geçici olmuştur. Türkiye-Ermenistan ilişkilerinde protokollerde öngörülen hedeflere ulaşılamadığı gibi, Azerbaycan-Ermenistan arasındaki Karabağ Sorununu da çözümsüzlügünü korumaktadır. Bugün Güney Kafkasya ülkeleri Gürcistan, Rusya ve Batı ile dengeli ilişkilerini korumaya devam etmektedir.

\section{6-Sonuç:}

2008 Rusya-Gürcistan Savaşı sadece beş gün sürmesine rağmen bölgedeki sonuçları beklenenden uzun sürdü. Savaş her ne kadar Gürcistan ile Güney Osetya arasındaki etnik anlaşmazlığa Rusya'nın müdahalesi ile çıkmışsa da sorun bir etnik anlaşmazlığın çok ötesinde idi. Rusya Gürcistan'a karşı orantısız güç kullanırken dünyaya ve bölge ülkelerine iki önemli mesaj vermek istedi. Bunlardan birincisi, Güney Kafkasya Bölgesindeki enerji koridorlarının Rusya'yı by-pass etmesine sessiz kalınmayacağı idi. İkinci olarak Rusya, sınırlarındaki ülkelerde yaşanan Renkli Devrim Hareketlerini bu ülkelerin iç dinamiklerinden kaynaklanan gelişmeler olarak değil Batı'nın yönlendirmesi olarak gördü ve bu ülkelerin Batı'ya yaklaşmalarına, NATO-AB gibi kuruluşlara üye olmalarına kayıtsız kalmayacağını gösterdi. Bu bakımdan Rusya'nın Gürcistan'a müdahalesi bu ülkedeki Gül Devrimine önemli bir darbe 
indirdi. Gürcistan'a müdahaleye uluslararası toplumun gösterdiği reaksiyonun beklenenden zayıf olması Rusya'yı daha da cesaretlendirdi. Eğer savaş nedeniyle Rusya'ya daha güçlü reaksiyon gösterilmiş olsaydı günümüzde Ukrayna'da yaşanan olaylara Rusya bu ölçüde müdahalede bulunamazdı. Gürcistan'ın yenilmesi sadece savaşın kaybedilmesi değil Gül Devrimi'nin de prestijini yitirmesi demekti. Bu nedenle savaştan sonra renkli devrim ülkelerinde demokrasiye ilgi azalırken otokratik liderler Rusya'ya daha çok yaklaşmaya başladılar. ( Krastev: 4 ) Savaştan sonra Gürcistan'da Batı'ya duyulan güvende büyük bir azalma meydana geldi. Kamuoyu ülkenin savaşta yaşadığı çöküşün Sakaşvili’nin aşırı Batı yanlısı politikalarının sonucu olduğunu kabul ederek hükümete karşı muhalefetini artırdı.

Savaştan sonra bölgede Gürcistan-Rusya ilişkileri belirsiz hale geldi. Taraflar arasında bir Ateşkes Anlaşması imzalanmasına rağmen Gürcistan'ın Güney Osetya ve Abhazya ile fiili bağlarının kesilmesi ve bağımsızlığını ilân eden bu bölgeleri Rusya'nın tanıması iki ülke ilişkilerinde garip bir durum yarattı. Bu gün iki ülke ne savaş halinde ne de barış halindedirler. ( Cicky: 7 ) Savaş sırasında Güney Osetya ve Abhazya Bölgelerindeki Gürcü kökenlilerin tamamına yakını Gürcistan'a sığındıkları için Gürcüsüz Gürcistan Özerk Bölgeleri gibi garip bir statü ortaya çıktı. Zaten uzun bir tarihi geçmişe sahip bu etnik anlaşmazlıklar geleceğin çözümsüz uluslararası sorunlar listesindeki yerini koruyacak gibi görünüyor. Savaştan sonra Rusya Gürcistan'da halkın Sakaşvili'yi devireceğinden umutlu olsa da bu beklenti gerçekleşmedi. Halk geniş gösterilerle Sakaşvili'yi istifaya çağırsa da 2012 Seçimlerine kadar koltuğunu korudu. 2012 Seçimlerinde hem parlamento hem de Devlet Başkanlığı seçimlerini Sakaşvili karşısında muhalefet adaylarının kazanması Gürcistan Halkının ülkeyi savaşa sokan Sakaşvili yönetiminden hoşnutsuzluğunun bir sonucu oldu.

Rusya-Gürcistan Savaşı sırasında Güney Kafkasya ülkelerinin tamamı tarafsız kalmayı tercih ettiler. Bu bölgede savaşın çok kısa sürmesi ve yayılmamasının en önemli nedeniydi. Türkiye'nin savaş sürecinde izlemiş olduğu tarafsız politika kapsamında ortaya attı̆̆ “ “ Kafkasya İstikrar Paktı " hayata geçmedi. Eğer bu girişim kabul görseydi Kafkasya'da barışı sağlama konusunda öncü ülke misyonu kazanılabilirdi. Ancak bir taraftan Batı'nın bu girişime gereken desteği vermemesi diğer taraftan Türkiye ile Ermenistan arasındaki ilişkilerin normalleşememesi sürecin resmiyet kazanmasını engelledi. Ancak, 2008 RusyaGürcistan Savaşı Türkiye ve bölgenin diğer ülkelerine Kafkasya'daki anlaşmazlıklara bulaşmamanın faydalarını da öğretti. Özellikle AB içindeki Güçlü ülkelerin Rusya’ya karşı yaptırım uygulama yerine anlaşmazlığı çözme yönündeki politikaları Türkiye'nin sorun karşısında tarafsız kalmasını kolaylaştırdı. Bunda hükümet kadar tarafsızlığa büyük önem veren muhalefet partileri ve sivil toplum örgütlerinin de katkısı vardı. Tarafsızlık politikasından kazançlı çıkan diğer bir ülke de Azerbaycan oldu. Eğer Azerbaycan kendisiyle benzer bir kaderi paylaşan Gürcistan'a destek vermeye kalkışsaydı Rusya'nın Karabağ'ın bağımsızlığını tanımasına da sebep olabilirdi. Azerbaycan böyle bir endişeyi göz önüne alarak Rusya ile yakınlaşmaya daha büyük önem vermeye başladı. Bu yakınlaşmada hidrokarbon kaynaklarını dünyaya ulaştırma sorunu da etkili oldu. Ancak Rusya'ya yakınlaşma politikasının Gürcistan ve Batı ile ilişkilere zarar vermeyecek şekilde yürütülmesi Azerbaycan dış politikasının bir başarısıydı. Kısaca belirtmek gerekirse, 2008 Rusya-Gürcistan Savaşından Güney Kafkasya Ülkeleri ekonomik bakımdan zararlı çıksalar da siyasi yönden başarılı bir sınav vermişlerdir. 


\section{REFERENCES}

- Alirıza, Bülent, “ Turkey and the Crisis in the Caucasus ", Center For Strategic International Studies, CSIS, Sep. 9, 2008.

- Antonenko, Oksana, “ Towards a Comprehensive Regional Security Framework in the Black Sea Region after the Russia-Georgia War “, Southeast European and Black Sea Studies, Vol. 9, No. 3, September 2009, pp. 259-269.

- Arbatova-Alexandrova, Nadia, “ The Impact of the Caucasus Crisis on Regional and European Security “, Southeast European and Black Sea Studies, Vol. 9, No. 3, September, 2009, pp. 287-300.

- Chicky, Jon E.,The Russian-Georgian War: Political and Military Implications for U.S. Policy, Johns Hopkins University, Central Asia-Caucasus Institute, Silk Road Program, February 2009.

- Chossudovsky, Michel, “ The Eurasian Corridor: Pipeline Geopolitics and the New Cold War “, Global Research, August 22, 2008.

- Donovan, George T.,Russian Operational Art in the Russo-Georgian War of 2008, USAWC STRATEGY RESEARCH PROJECT, 2009.

- Foucher, Michel/Giuliani, Jean Dominique, The European Union And The RussoGeorgian War, The Robert Schuman Foundation, European Issues Report, 1 September 2008.

- Karabayram, Fırat, Güney Kafkasya Jeopolitiğinde Rusya Gerçeği, IQ Yayıncılık, İstanbul, 2011.

- Kimitaka, Matsuzato, “ The Five-Day War and Transnational Politics, A Semiospace Spanning the Borders between Georgia, Russia and Ossetia “, Demokratızatsıya, 2009, pp. 228-250.

- Kirdar, Seda, “ Conflict Resolution in Georgia: An Analysis Applying The Intractable Conflict Theory and the Govermental Politics Model “, Perceptions, Winter 2008, pp. 51-71.

- Krastev, Ivan, “ Russia and the Georgia War: the great power trap “, Open Democracy, 08,31, 2008, http://www.opendemocracy.net.

- Mikhelidze, Nona, “ After the 2008 Russia-Georgia War: Implications for the Wider Caucasus and Prospects for Western Involvement in Conflict Resolution “, Institute Affari Internazionali Documanti IAI 0901, 2009, pp. 1-25.

- Milliyet.

- New York Times.

- Nichol, Jim, Russia-Georgian Conflict in August 2008: Context and Implications for U.S. Interests, Congressional Research Service, 7-5700, RL34618, March 3, 2009, www.crs.gov.

- Papava, Viladimir, “ Georgia’s Economy: Post-revolutionary Development and Postwar Difficulties “, Central Asian Survey, Vol. 28, No. 2, June 2009, pp. 199-213.

- Sushko, Oleksandr, “ The end of International Order-1991: Impact of 2008 RussiaGeorgia War on Ukraine “, HEINRICH BÖLL STIFTUNG; WARSAW; Nov. 2008.

- Valiyev, Anar, “ Azerbaijan’s Foreign Policy Since the Russian-Georgian War “, PONARS Eurasia Policy Memo. No. 12, 2010. 